\title{
COMPARATIVE CYTOGENETIC ANALYSIS OF DIPLOID AND HEXAPLOID CHENOPODIUM ALBUM Agg.
}

\author{
Bożena Kolano, Dorota SiwińsKa, Jolanta MaŁuszyńsKa \\ Department of Plant Anatomy and Cytology, University of Silesia \\ Jagiellońska 28, 40-032 Katowice, Poland \\ e-mail: bozena.kolano@us.edu.pl
}

(Received: May 18, 2007. Accepted: December 6, 2007)

\begin{abstract}
Two cytotypes of Chenopodium album, diploid $(2 \mathrm{n}=2 \mathrm{x}=18)$ and hexaploid $(2 \mathrm{n}=6 \mathrm{x}=54)$, were analysed using flow cytometry and a FISH experiment. The genome size was indicated as $1.795 \mathrm{pg}$ for the diploid and $3.845 \mathrm{pg}$ for the hexaploid plants which suggested genome downsizing in the evolution of hexaploid cytotype. Double FISH with 25S rDNA and 5S rDNA allowed three to five homologue chromosome pairs to be distinguished depending on the cytotype. The variation in size and number of rDNA sites between the polyploid C. album and its putative diploid ancestor indicated that rDNA loci underwent rearrangements after polyploidization.

Flow cytometry measurements of the relative nuclear DNA content in the somatic tissue of C. album revealed extensive endopolyploidization resulting in tissues comprising a mixture of cells with a different DNA content (from $2 \mathrm{C}$ to $32 \mathrm{C}$ ) in varying proportions. The pattern of endopolyploidy was characteristic for the developmental stage of the plant and for the individual organ. Polysomaty was not observed in the embryo tissues however endopolyploidization had taken place in most tested organs of seedlings. The endopolyploidy in diploid and hexaploid C. album was compared to find any relationship between the pattern of polysomaty and polyploidy level in this species. This revealed that polyploid plants showed a decline in the number of endocycles as well as in the frequency of endopolyploidy cells compared to diploid plants.
\end{abstract}

KEY WORDS: Chenopodium, polyploid, genome size, rDNA sequence, flow cytometry, polysomaty.

\section{INTRODUCTION}

Polyploidy species are common among angiosperm plants. It is estimated that approximately $80 \%$ of flowering plants underwent a polyploidization event during their evolution (Soltis and Soltis 1993; Masterson 1994; Bennett 2004). Polyploids exhibit distinctive morphological, physiological and life history characteristics that may allow plants to colonize new habitats or expand their geographical range (Otto and Whitton 2000; Ramsey and Schemske 2002; Borgen and Hultgard 2003).

As indicated for many species, polyploidization was followed by dramatic genome rearrangements, which often led to genome downsizing and chromosomal changes (Leitch and Bennett 2004; Lim et al. 2004). The mechanisms that are responsible for polyploidy genome rearrangements are still not well known, but most often translocations, elimination of repetitive sequences, activation of transposable elements and homoeologous recombination have been proposed (Wendel 2000; Bennetzen 2002; Kidwell 2002). One of the repetitive sequences often used in genome analysis are rRNA genes. Their tandem organization, high copy number and conserved nature throughout the plant kingdom (Maluszynska et al. 1998) make them suitable mar- kers for chromosome identification and karyotyping in many different plant genera such as Brassica, Lupinus, Hypochaeris, Hordeum (Kulak et al. 2002; Hajdera et al. 2003; Weiss-Schneeweiss 2003; Takate et al. 2005). The localization and number of the gene loci can change in evolving polyploids as for Scilla autumnalis described Vaughan et al. (1993).

Besides generative polyploidization many angiosperm species undergo somatic polyploidization during development. Endopolyploidization of nuclear DNA is a common feature of eucaryots and occurs in over $90 \%$ of all angiosperms. The variation of cell ploidy levels designated as somatic polyploidy is a developmental process that involves one or more rounds of nuclear DNA synthesis without chromosomal and cellular division and leads to endopolyploidy (D’Amato 1989; Trass et al. 1998; Małuszyńska and Siwińska 2004). Although somatic polyploidy was found in most angiosperms, in some species like Crepis capillaries there are no endopolyploid cells in any tissue (Małuszyńska 1990).

Chenopodium album is a complex species and consists of highly heteromorphic wild and semi-cultivated forms (Wilson 1990; Gangopadhyay et al. 2002). Cytologically, it comprises diploid $(2 n=2 x=18)$, tetraploid $(2 n=4 x=36)$ 
and hexaploid $(2 \mathrm{n}=6 \mathrm{x}=54)$ cytotypes (Tanaka and Tanaka 1980; Partap et al. 1985; Bhargava et al. 2005). This study was undertaken to find relationships between the polyploidy level, genome size and numbers of rDNA loci in a $C$. album complex. We also decided to investigate whether the polyploidy level of the C. album plant has an impact on the endopolyploidy pattern during plant development.

\section{MATERIALS AND METHODS}

\section{Plant material and DNA probes}

Seeds of the diploid C. album $(2 \mathrm{n}=18)$ derived from the Botanic Garden in Berlin-Dahlem and the hexaploid C. album $(2 \mathrm{n}=6 \mathrm{x}=54)$ which came from Hortus Botanicus Universitatis "Friedrich Schiller" Jena (Germany) were used. The plants were cultivated in pots in the growth chamber of Silesian University.

The 5S rDNA 410 bp clone isolated from Triticum aestivum (Gerlach and Dyer 1980) was amplified and directly labelled using PCR with rhodamine-4-dUTP. The $2.3 \mathrm{~kb}$ sub-clone of the 25S rDNA coding region of Arabidopsis thaliana (Unfriend and Grueler 1990), labelled with digoxigenine-11-dUTP by nick translation, was used for detection of $18 \mathrm{~S}-5.8 \mathrm{~S}-25 \mathrm{~S}$ rDNA.

\section{Chromosome preparation and FISH}

Chromosome preparations according to Maughan et al. (2006) were prepared from young leaves and shoot meristems. Methods of in situ hybridization were adapted from Schwarzacher and Heslop-Harrison (2000) with some modification. The hybridization mixture, consisting of $100 \mathrm{ng}$ labelled DNA probe, $50 \%$ formamide, $10 \%$ dextran sulphate, $0,1 \%$ SDS (sodium dodecyl sulphate) and $10 \mu \mathrm{g}$ of sheared salmon sperm DNA, was denatured for $10 \mathrm{~min}$. at $85^{\circ} \mathrm{C}$, then chilled for $5 \mathrm{~min}$. on ice and applied to the chromosome preparations. The slides and hybridization mixture were then denatured together at $72^{\circ} \mathrm{C}$ for $5 \mathrm{~min}$. in an in situ Thermal Cycler (Hybaid) and incubated at $37^{\circ} \mathrm{C}$ overnight. Stringent washes $\left(20 \%\right.$ formamide in $0.1 \times \mathrm{SSC}$ at $42^{\circ} \mathrm{C}$ ) were followed by immunodetection of a digoxygenete
DNA probe with FITC-conjugated antibodies (Roche). The preparations were mounted in Vectashield containing $2 \mu \mathrm{g} / \mathrm{ml} \mathrm{DAPI}$ and stored at $4^{\circ} \mathrm{C}$. Slides were analysed using an Olympus AX 70 microscope and all pictures were taken using a Hamamatsu (C5810) CCD camera. Pictures were uniformly processed and superimposed using Micrografx Picture Publisher software.

\section{Flow cytometry analysis}

Young leaves were used for measuring nuclear DNA content. The samples were prepared according to a twostep protocol (Doležel et Göhde 1995) and nuclei were stained with PI (propidium iodide). For each sample at least 10000 nuclei were analysed. Samples were measured using a DAKO Galaxy flow cytometer equipped with an air-cooled argon ion laser. The nuclear DNA content of the accessions of Chenopodium album was calculated using nuclei isolated from young leaves of Glycine max cv. Polanka (2C DNA - $2.50 \mathrm{pg}$, Dolezel et al. 1994) as an internal standard. The value of 2C DNA was estimated as an average of 30 measurements for each cytotype.

The endopolyploidy pattern was obtained for embryos isolated from soaked seeds and for seedlings in the stage of open cotyledons. The diploid plant reached the second stage of development after three days of growth and the hexaploid in the fifth day after germination. Flow cytometry analysis in seedlings was prepared separately for particular parts: radicles, root tips, differentiated root parts, hypocotyls and cotyledons. To release nuclei the tissue sample was chopped with a razor blade in a nuclei extraction buffer (Doležel et Göhde 1995), filtered through a 30 um nylon sieve (Partec Cell Trics) and stained with DAPI (4,6-diamidino-2-phenylindole). Each sample consisted of tissue from 10 different plants and for each sample 10000 nuclei were analysed. At least three replicates were subjected to analysis. The DNA content of the isolated nuclei in the samples were analysed using a DAKO Galaxy flow cytometer equipped with an HBO-100 mercury lamp and the set of filters and mirrors (KG1, UG1, BG38, TK420 and GG435). The FloMax software processed data were plotted on a semilogarithmic scale.

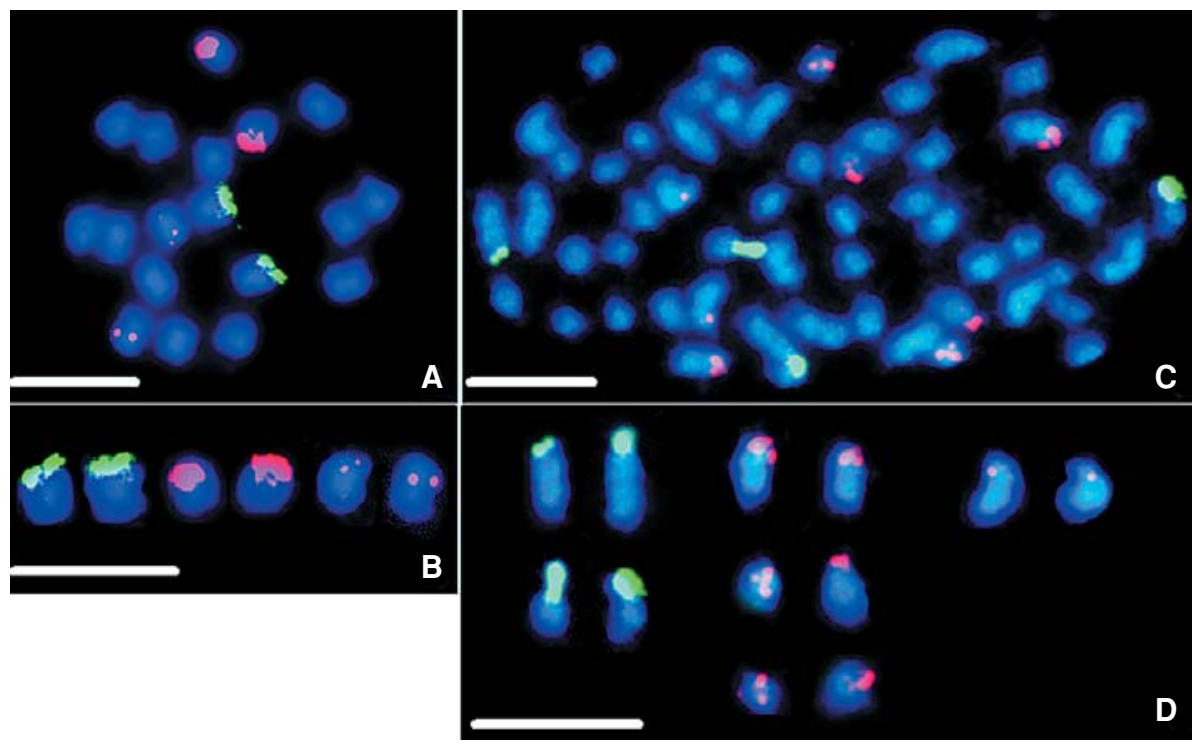

Fig. 1. Fluorescence in situ hybridization of the 25S rDNA (green) and 5S rDNA (red) sequences to diploid $(\mathrm{a}, \mathrm{b})$ and hexaploid $(\mathrm{c}$, d) C. album chromosomes. 


\section{RESULTS}

\section{Genome of C. album}

The analysed accessions of $C$. album exhibit two different ploidy levels: diploid and hexaploid with the basic chromosome number $\mathrm{x}=9$. The somatic metaphase chromosomes of C. album cytotypes are shown in Figure 1. Diploid plants possess $2 \mathrm{n}=2 \mathrm{x}=18$ chromosomes whose size ranges from 1.4 to $2.7 \mathrm{~mm}$. Hexaploid plants were characterized by $2 \mathrm{n}=6 \mathrm{x}=54$ slightly shorter chromosomes and their size was between 1.0 to $2.6 \mu \mathrm{m}$.

The genome size of the $C$. album plant was established using a flow cytometry analysis of propidium iodide-stained nuclei. Measurements resulted in histograms with two dominant peaks corresponding to the 2C DNA nuclei of $C$. album and glycine. The 2C DNA content was determined as $1.8 \mathrm{pg} \pm 0.02$ for the diploid and $3.85 \mathrm{pg} \pm 0.03$ for the hexaploid.

Fluorescent in situ hybridization with $5 \mathrm{~S}$ rDNA and 25S rDNA to $C$. album chromosomes reveals hybridization signals only in the terminal parts of chromosomes. The diploid cytotype showed one pair of 25S rDNA sites and two pairs of 5S rDNA sites. The 5S rDNA hybridization signals showed differences in size and intensity. This allowed three pairs of homologue chromosomes to be distinguished (Fig. 1a, b). The hexaploid cytotype displayed two pairs of 25S rDNA loci and four pairs of 5S rDNA loci (Fig. 1c, d). Chromosomes that carry 25S rRNA genes differ in size, which allowed two pairs of homologue chromosomes to be distinguished. In the hexaploid genome, similar to the diploid, 5S rDNA loci differed in fluorescence signal intensity. Six chromosomes exhibited a relatively strong 5S rDNA signal. The chromosomes have a very similar morphology so it was impossible to recognize the homologue pairs. Additionally, one pair of chromosomes carried loci with fewer 5S rDNA repeats and revealed weaker hybridization signals (Fig. 1c, d). Double FISH with rRNA genes to hexaploid $C$. album allowed three pairs of homologue chromosomes to be distinguished and differentiated a group of six chromosomes carrying $5 \mathrm{~S}$ rDNA sequences.

\section{Endopolyploidy in C. album}

Ploidy patterns of $C$. album were obtained for two different stages of plant development: embryos isolated from imbibited seeds and seedlings in the stage of open cotyledons. The patterns of endopolyploidy obtained for embryos of diploid and hexaploid cytotypes were similar. The embryos mainly contained cells with $2 \mathrm{C}$ or $4 \mathrm{C}$ DNA (Fig. 2). For both cytotypes of $C$. album, 2C DNA picks were large

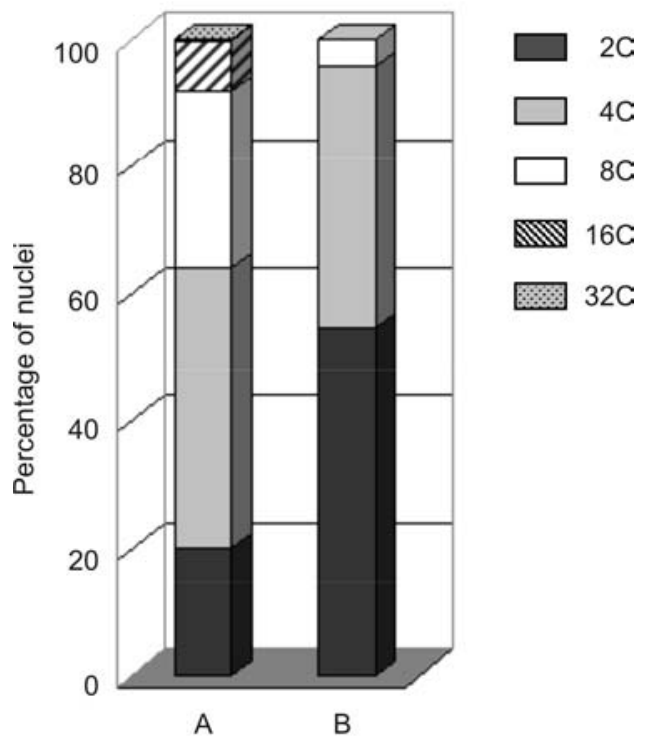

Fig. 3. Average frequency of nuclei with various DNA content in C. album seedlings: (A) diploid and (B) hexaploid.

and contained about $90 \%$ of the total nuclei. The picks for 4C DNA nuclei were small.

By contrast in the stage of open cotyledons, diploid and hexaploid seedlings showed different endopolyploidy patterns (Fig. 3). Diploid C. album revealed a high number of endopolyploid nuclei. Nearly $40 \%$ of the cells had DNA content higher then 4C (Fig. 3). A detailed flow cytometry analysis revealed that endopolyploid cells existed in all analysed organs and that particular organs exhibit different patterns of polysomaty (Fig. 4). Differentiated root parts displayed the highest level of endopolyploidization where only $45 \%$ of the cells possessed $2 \mathrm{C}$ or $4 \mathrm{C}$ DNA and only in this part of seedlings were cells with 32C DNA (Fig. 4). Endopolyploid cells were also observed in root tips where nearly $40 \%$ of the cells have an $8 \mathrm{C}$ or $16 \mathrm{C}$ DNA level. The lowest level of polysomaty was observed in cotyledons. These seedling organs revealed only $2 \mathrm{C}, 4 \mathrm{C}$ and $8 \mathrm{C}$ DNA nuclei and the number of nuclei with DNA content higher than $4 \mathrm{C}$ was $7 \%$ (Fig. 4).

A relatively lower level of endopolyploidization was observed in the hexaploid $C$. album. It was revealed that hexaploid plants showed a decline in the number of endocycles as well as in the frequency of endopolyploid cells compared to diploid plants. More than $90 \%$ of the cells had a $2 \mathrm{C}$ or $4 \mathrm{C}$ DNA content and a very small number of cells with 8C DNA were observed (Fig. 3). In the all analysed

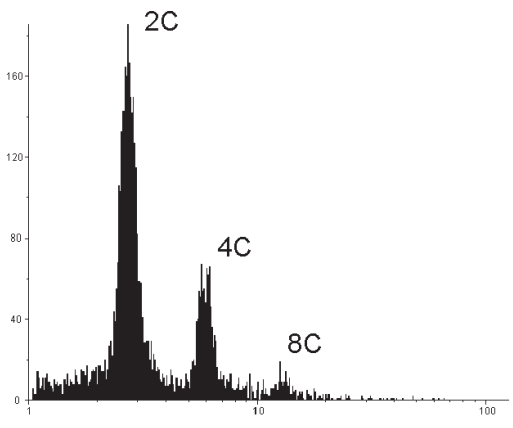

diploid $2 n=2 x=18$

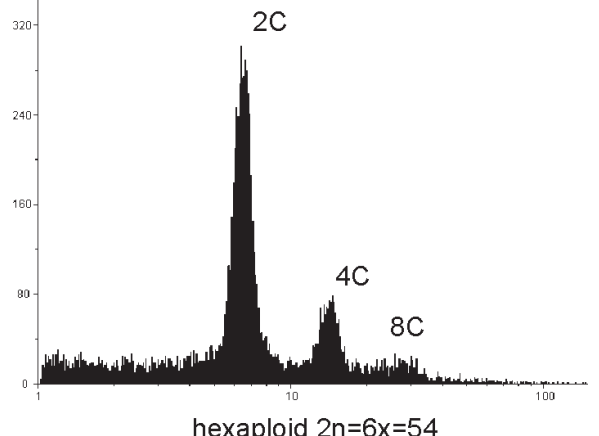

hexaploid $2 n=6 x=54$
Fig. 2. Typical flow cytomeric histograms (log scale) of the nuclei isolated from diploid (A) and hexaploid (B) C. album embryos. 

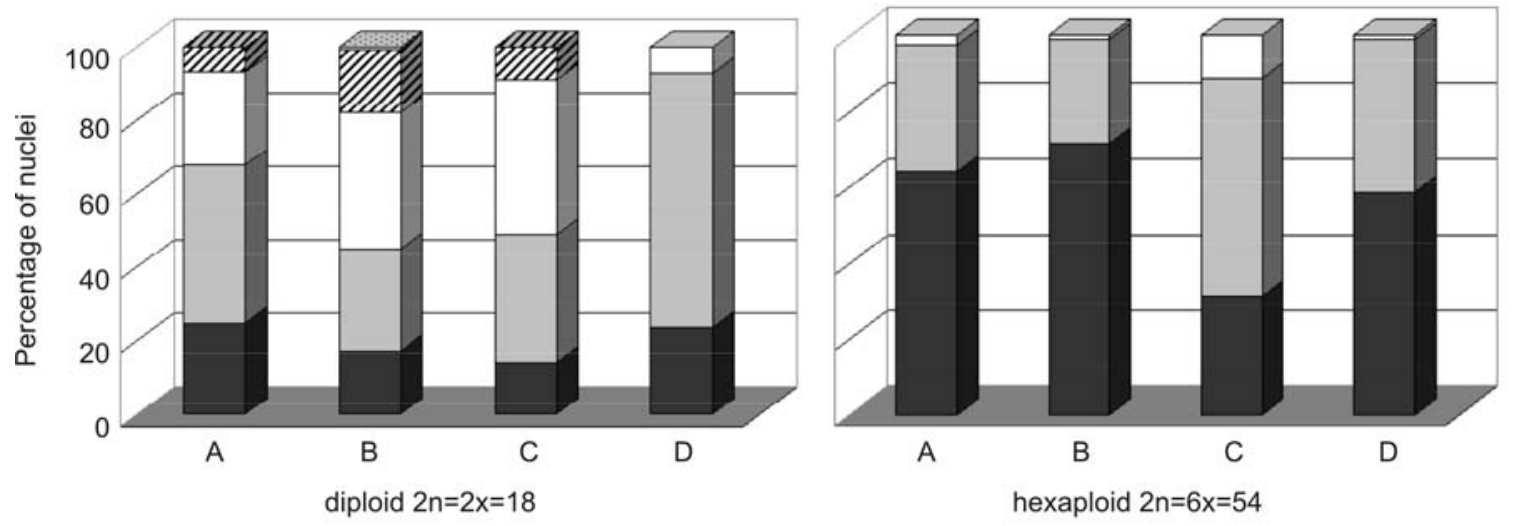

$\square 2 \mathrm{C} \quad \square$ 4C $\square 8 \mathrm{C} \quad$ 16C $32 \mathrm{C}$

Fig. 4. Frequency of the nuclei with various DNA content in diploid and hexaploid C. album seedlings in stage of open cotyledons. (A) root tip, (B) differentiated part of root, (C) hypocotyl, (D) cotyledons.

hexaploid organs, cells with 2C and 4C DNA dominated but the endopolyploidy pattern was different for the every organ (Fig. 4). The lowest level of polysomaty was found in cotyledons and the differentiated part of a root where only $1 \%$ of the cells have DNA content higher than $4 \mathrm{C}$. More endopolyploid cells were observed in root tips (2.5\%) and hypocotyls. The hypocotyls, where $11 \%$ of the cells have an 8C DNA content, showed the highest level of polysomaty (Fig. 4). The hypocotyl was also the seedling part with the lowest level of cells with a 2C DNA content. Additionally, we checked the endopolyploidy level in mature leaves. In both diploid and hexaploid plants a lack of endopolyploidy was observed in these organs (data not shown).

\section{DISCUSSION}

\section{Genome of C. album}

The analysed $C$. album accessions represent two different ploidy levels and possess $2 n=18$ (diploid) or $2 n=54$ (hexaploid) chromosomes. Our results are in agreement with earlier data that described the $C$. album plant with diploid, tetraploid and hexaploid chromosome number (Tanaka and Tanaka 1980; Partap and Kapoor 1985) and support the hypothesis that $C$. album is a polyploidy complex. The origin of the polyploidy $C$. album is still unclear and there are reports suggesting that hexaploid $C$. album could be an allo- not autopolyploid plant (Gangopadhyay et al. 2002; Kolano et al. 2006). The genome size of diploid and hexaploid $C$. album was assumed to be $1.795 \mathrm{pg}$ and 3.846 pg respectively. Our results differ from data obtained earlier. The diploid C. album plant analyzed by Ohrii (2002) had a smaller genome size $1.54 \mathrm{pg} / 2 \mathrm{C}$ DNA and the hexaploid had a larger 2C DNA value (4.66 pg). C. album is a widespread and variable species so the revealed differences could represent karyotypical and genetic differences among different populations. Intraspecific variations in genome size (not connected with different ploidy levels) have been reported earlier for some species like Zea mays or Glycine max (Rayburn et al. 1997; Rayburn et al 2004). The variations were connected with different geographical localizations as for Arabidopsis thaliana (Schmuths et al. 2004) or different altitudes as for Dactylis glomerata (Reeves et al. 1998).

The hexaploid $C$. album analyzed in this study has a genome that is twice as large as that of a diploid. Polyploids often have a somewhat lower genome size than expected from their diploid relatives (Song et al. 1995; Leitch and Bennett 2004; Cavalier-Smith 2005). The mechanisms, which lead to genome downsizing in polyploids are still not understood although there are many analyses which have shown that the elimination of duplicated genes and loss of repetitive sequences could be the reasons. The elimination of DNA sequences from polyploid genomes was reported for a few species, for example Ranunculus, the Aegilops-Triticum group and Nicotiana (Horandl and Greilhuber 2002; Ozkan et al. 2003; Narayan 1998).

The elimination of rRNA genes from polyploid genomes is well-documented. A comparative analysis of the number, localization and intensity of rDNA-FISH signals in polyploid and their diploid ancestors allowed researchers to follow the chromosome evolution in polyploids in many cases (Maluszynska and Heslop-Harrison 1993; Vaughan et al. 1993; Hasterok and Maluszynska 2000). The comparative study showed a non-additive distribution pattern of $25 \mathrm{~S}$ and $5 \mathrm{~S}$ rDNA loci in the polyploid C. album. FISH results indicated that there was a loss of one locus of 25S rDNA in the hexaploid (Fig. 1). Additionally the chromosome pairs that bear the $25 \mathrm{~S}$ rDNA loci had a different morphology (Fig. 1c). This suggested that chromosome rearrangement involving 25S rDNA locus happened after polyploidization. In the case of 5S rRNA genes the loss of site number concerned only the locus with weak hybridization signals. The number of strong 5S rDNA signals in the hexaploid was as expected when compared with a diploid plant. The rearrangement of rDNA sites has been reported in the evolution of other polyploids, for example Arabidopsis, Camellia, Brassica (Weiss and Maluszynska 2001; $\mathrm{Gu}$ et Xiao 2003; Hasterok et al. 2006). Polyploidy genome downsizing caused by the loss of repetitive sequences could be an adaptative response to the genomic stress caused by polyploidization, which serves to stabilize the polyploidy genome (Ozkan et al. 2003). 
Comparison of polysomaty in diploid and hexaploid C. album plants

The connection between generative and somatic polyploidy is still unclear. In some species such as Beta vulgaris and Zea mays, polyploid plants have a lower level of endopolyploid cells than diploids, but on the other hand, diploid and tetraploid tomato plants exhibit the same pattern of polysomaty (Biradar et al. 1993; Smulders et al. 1994; Sliwinska and Lukaszewska 2005).

In this study we compared polysomaty patterns in diploid and hexaploid C. album. The plants used for this study were at a comparable stage of development and were grown in the same conditions. The results obtained for embryos isolated from imbibited seeds were similar for diploid and hexaploid cytotypes. The embryos mainly contained cells with a $2 \mathrm{C}$ and 4C DNA content although a small pick for 8C DNA was observed. Earlier researches also showed that embryo tissues consist mostly of cells with 2C DNA ( $F a$ gus silvatica, Pinus nigra, Cichorium endive) or $2 \mathrm{C}$ and 4C DNA (Rahanus sativus) although there are species whose embryos contains some endopolyploid cells (Spinacia oleracea, Cucumis sativus) (Bino et al. 1993; Gilissen et al. 1993). The additional 8C DNA pick for C. album embryos indicated that endopolyploidization took place in a small number of cells at the early stages of tissue differentiation during embryo development. Then during seedling development, the number of endopolyploid cells rose. An increase of endopolyploidy often occurs with age and it is believed that a higher DNA content might be needed to sustain the larger cell volume (Galbraith et al. 1991; Kondrosi et al. 2000). Remarkably, there was a lack of endopolyploidization in both diploid and hexaploid C. album leaves which is in contrast with the observation of Arabidopsis, Lycopersicon, and Brassica (Galbraith et al. 1991; Smulders et al. 1994; Kudo and Kimura 2001). The results obtained in this study showed that although endopolyploidy occurs in diploid and hexaploid plant, the level of the occurrence differs. The diploid $C$. album seedlings had a pattern of polysomaty that consisted of 2C-32C DNA cells and existed in most analysed organs, even in the root tip. Meristematic tissue usually contains cells with $2 \mathrm{C}$ or 4C DNA. However, some reports have described endopolyploid cells in root meristems of other Chenopodium species (Wang et al. 1993). The presence of endopolyploid cells in the root tip could be connected with methaxylem cell differentiation (Baluska 1990).

The polysomaty pattern in the hexaploid plant was different than in the diploid. The highest level of endopolysomaty observed in hexaploid seedlings was 8C DNA and the hexaploid $C$. album contained fewer cells with a DNA content higher than $4 \mathrm{C}$. In the hexaploid the average endopolyploid cell content was lower than $5 \%$ whereas in the diploid it was approximately $40 \%$. This is in agreement with data obtained for diploid, triploid and tetraploid accessions of Beta vulgaris (Sliwinska and Lukaszewska 2005). A comparison of polysomaty development between $B$. vulgaris plants of different ploidy level showed that the number of endocycles is negative correlated with the plant ploidy level. A similar tendency was observed in diploid and tetraploid Zea mays and Portulaca grandiflora. However, in these two species the number of endocycles was the same but the level of endopolyploid cells was higher in the diploid than in the polyploidy plant (Biradar et al. 1993; Mishiba and Mii 2000).

Our results indicated that endopolyploidization is an integral part of the differentiation process in C. album but there is negative correlation between genome size and the number of endocycles. In a hexaploid plant most of the cells have a $2 \mathrm{C}$ or $4 \mathrm{C}$ DNA content and the level of endopolyploidization is much lower than in diploids. This suggests that in this species a certain maximum nuclear DNA content is programmed rather than the number of endocycles.

\section{LITERATURE CITED}

BALUSKA F. 1990. Nuclear size, DNA content, and chromatine condensation are different in individual tissues of the maize root apex. Protoplasma 158: 45-58.

BENNETT M.D. 2004. Perspectives on polyploidy in plants - ancient and neo. Biol. J. Linn. Soc. 82: 411-423.

BENNETZEN J.L. 2002. Mechanizm and rates of genome expansion and contraction in flowering plants. Genetica 115: 29-36.

BHARGAVA A., SHUKLA S., OHRI D. 2005. Karyotypic studies on some cultivated and wild species of Chenopodium (Chenopodiaceae). Genet. Resour. Crop Evol. 53: 1309-1320.

BINO R.J., LANTERI S., VERHOEVEN H.A., KRAAK H.L. 1993. Flow cytometric determination of nuclear replication stages in seed tissues. Ann. Bot. 72: 181-187.

BIRADAR D.P., RAYBURN A L., BULLOCK D.G. 1993. Endopolyploidy in diploid and tetraploid maize (Zea mays L.) Ann. Bot. 71: 417-421.

BORGEN L., HULTGARD U. 2003. Parnassia palustris: a genetically diverse species in Scandinavia. Bot. J. Linn. Soc. 142: 347-372.

CAVALIER-SMITH T. 2005. Economy, speed and size matter: evolutionary forces driving nuclear genome miniaturization and expansion. Ann. Bot. 95: 147-175.

D'AMATO F. 1989. Polyploidy in cell differentiation. Cariologia 42: $183-211$

DOLEZEL J., DOLEZELOVA M., NOVAK F.J. 1994. Flow cytometric estimation of nuclear DNA amount in diploid bananas (Musa acuminata and M. balbisiana). Biol. Plant. 36: 351$-357$.

DOLEŽEL J., GÖHDE W. 1995. Sex determination in dioecious plants Melandrium album and M. rubrum using high-resolution flow cytometry. Cytometry 19: 103-106.

GALBRAITH D.W., HARKINS K.R., KNAPP S. 1991. Systemic endopolyploidy in Arabidopsis thaliana. Plant Physiol. 96: 985-989.

GANGOPADHYAY G., DAS S., MUKHWRJEE K.K. 2002. Speciation in Chenopodium in West Bengal, India. Gene. Resou. Crop Evol., 49: 503-510.

GERLACH W.L., DYER T.A. 1980. Sequence organization of the repeating units in the nucleus of wheat, which contain 5S rRNA genes. Nucl. Acids Res. 11: 4851-4865.

GILISSEN L.J.W., VAN STAVEREN M.J., CREEMERS-MOLENAAR J., VERHOEVEN H.A. 1993. Development of polysomaty in seedling and plants of Cucumis sativus. Plant Sci. 91: 171-179.

GU Z., XIAO H. 2003. Physical mapping of the 18S-26S rDNA by fluorescent in situ hybridization (FISH) in Camellia reticulata polyploidy complex (Theaceae). Plant Sci. 164: 279-285.

HAJDERA I., SIWINSKA D., HASTEROK R., MALUSZYNSKA J. 2003. Molecular cytogenetic analysis of genome structure in Lupinus angustifolius and Lupinus cosentinii. Theor. Appl. Genet. 107: 988-996.

HASTEROK, R., MALUSZYNSKA, J. 2000. Nucleolar dominance does not occure in root tip cells of allotetraploid Brassica species. Genome 43: 574-579. 
HASTEROK R., WOLNY E., HOSIAWA M., KOWALCZYK M., KULAK-KSIAZCZYK S., KSIAZCZYK T., HENEEN W.K., MALUSZYNSKA J. 2006. Comparative analysis of rDNA distribution in chromosomes of various species of Brassicaceae. Ann. Bot. 97: 205-216.

HORANDL E., GREILHUBER J. 2002. Diploid and autotetraploid sexuals and thier relationships to apomicts in the Ranunculus cassubicus group: insights from DNA content and isozyme variation. Plant Syst. Evol. 234: 85-100.

JAKOB S.S., MEISTER A., BLATTNER F.R. 2004. The considerable genome size variation of Hordeum species (Poaceae) is linked to phylogeny, life form, ecology, and speciation rates. Mol. Biol. Evol. 21: 860-869.

KIDWELL M.G., 2002. Transposable elements and the evolution of genome size in eukaryotes. Genetica 115: 49-63.

KOLANO B., SIWIŃSKA D., MAŁUSZYŃSKA J. 2006. Molecular cytogenetic analysis of genome structure in Chenopodium album complex. Variability and Evolution-New Perspective 72: 507-517.

KONDOROSI E., ROUDIER F., GENDREAU E. 2000. Plant cell-size control: growing by ploidy? Curr. Opin. Plant Biol. 3: 488-492.

KUDO N., KIMURA Y. 2001. Patterns of endopolyploidy during seedling development in cabbage (Brassica oleracea L.). Ann. Bot. 87: 275-281.

KULAK S., HASTEROK R., MALUSZYNSKA J. 2002. Kariotyping of Brassica amphidiploids using 5S and 25S rDNA as chromosome markers. Hereditas 136: 144-150.

LEITCH I.J., BENNETT D. 2004. Genome downsizing in polyploid plants. Biol. J. Lin. Soc. 82: 651-663.

LIM K.Y., MATYASEK R., KOVARIK A., LEITCH A.R. 2004. Genome evolution in allotetraploid Nicotiana. Biol. J. Lin. Soc. 82: 599-606.

MAŁUSZYŃSKA J. 1990. B chromosomes of Crepis capillaries (L.) Waller. In vivo and in vitro. University of Silesia, Katowice.

MALUSZYNSKA J., HASTEROK R., WEISS H. 1998 rRNA genes - their distribution and activity in plants. In: Maluszynska J. (ed.) Plant cytogenetics. Cieszyn, Poland, pp. 75-95.

MALUSZYNSKA J., HESLOP-HARRISON J.S. 1993. Physical mapping of rDNA loci in Brassica species. Genome 36: 774-781.

MAŁUSZYŃSKA J., SIWIŃSKA D. 2004. Wielkość genomu roślinnego. Post. Biol. Kom. 31: 101-114.

MASTERSON J. 1994. Stomatal size in fossil plants: evidence for polyploidy in majority of angiosperms. Science 264: 421$-424$.

MAUGHAN P.J., KOLANO B.A., MALUSZYNSKA J., COLES N.D., BONIFACIO A., ROJAS J., COLEMAN C.E., STEVENS M.R., FAIRBANKS D.J., PARKINSON S.E., JELLEN E.N. 2006. Molecular and cytological characterization of ribosomal RNA genes in Chenopodium quinoa and Chenopodium berlandieri. Genome 49: 825-839

MISHIBA K., MII M. 2000. Polysomaty analysis in diploid and tetraploid Portulaca grandiflora. Plant Sci. 156: 213-219.

NARAYAN R.K.J. 1998. The role of genomic constraints upon evolutionary changes in genome size and chromosome organization. Ann. Bot. 82: 57-66.

OHRII G. 2002. In: Bennett M.D., Leitch I.J. 2004. Angiosperm DNA C-values database. http: //www.rbgkew.org.uk/cval/homepage.html.

OTTO S.P., WHITTON J. 2000. Polyploid incidence and evolution. Annu. Rev. Genet. 34: 401-437.

OZKAN H., TUNA T., ARUMUGANATHAN K. 2003. Nonadditive changes in genome size during allopolyploidization in the wheat (Aegilops-Triticum) group. J. Heredity 94: 260-264.
PARTAP T., KAPOOR P. 1985. The Himalayan grain chenopods. II. Comparative morphology. Agriculture, Ecosystems and Environment 14: 201-220.

RAMSEY J., SCHEMSKE D.W. 2002. Neopolyploidy in flowering plants. Annu. Rev. Ecol. Syst. 33: 589-693.

REEVES G., FRANCIS D., DAVIES M.S., ROGERS H.J., HODKINSON T.R. 1998. Genome size is negatively correlated with altitude in natural populations of Dactylis glomerata. Ann. Bot. 82: 99-105.

RAYBURN A.L., BIRDAR D.P., BULLOCK D.G., NELSON R.L., GOURMET C., WETZEL J.B. 1997. Nuclear DNA content diversity in Chinese soybean introductions. Ann. Bot. 80: 321-325.

RAYBURN A.L., BIRADAR D.P., NELSON R.L., MCCLOSKEY R., YEATER K.M. 2004. Documenting intraspecfic genome size variation in soybean. Crop Science 44: 261-264.

SCHMUTHS H., MEISTER A., HORRES R., BACHMANN K. 2004. Genome size variation among accessions of Arabidopsis thaliana. Ann. Bot. 93: 317-321.

SCHWARZACHER T., HESLOP-HARRISON P. 2000. Practical in situ Hybridization. BIOS Scientific Publisher Limited, Oxford.

SMULDERS M.J.M., RUS-KORTEKAAS W., GILISSEN L.J.W. 1994. Development of polysomaty during differentiation in diploid and tetraploid tomato (Lycopersicon esculentum) plants. Plant Sci. 97: 53-60.

SLIWINSKA E., LUKASZEWSKA E. 2005. Polysomaty in growing in vitro sugar-beet (Beta vulgaris L.) seedlings of different ploidy level. Plant Sci. 168: 1067-1074.

SOLTIS D.E., SOLTIS P.S. 1993. Molecular data and the dynamic nature of polyploidy. Critical Reviews in Plant Sci. 12: 243-273.

SONG K., TANGK L.P., OSBORN T.C. 1995. Rapid genome changes in syntetic polyploids of Brassica and its implications for polyploids evolution. PNAS 92: 7719-7723.

TANAKA R., TANAKA A. 1980. Karyomorphological studies on halophytic plants. I. Same taxa of Chenopodium. Cytologia 45: 257-269.

TAKATE S., ANDO H., TAKEDA K., ICHII M., BOTHMER R. 2005. Ancestry of American polyploid Hordeum species with the I genome inferred from 5S and 18S-25S rDNA. Ann. Bot. 96: 23-33.

TRAAS J., HULSKAMP M., GENDREAU E., HOFTE H. 1998. Endoreduplication and development: rule without dividing? Curr. Opin. Plant Biol. 1: 498-503.

UNFRIEND I., GRUENDLER P. 1990. Nucleotide sequence of the 5.8S and 25S rRNA genes and the internal transcribed spacers from Arabidopsis thaliana. Nucl. Acids Res. 18: 4011.

VAUGHAN H.E., JAMILENA M., RUIZ REJON M., PARKER J.S., GARRIDO-RAMOS M.A. 1993. Loss of nucleolar-organizer regions during polyploid evolution in Scilla autumnalis. Heredity 71: 574-580.

WANG S., TSUCHIYA T., WILSON H.D. 1993. Chromosome studies in several species of Chenopodium from North and South America. J. Genet. \& Breed., 47: 163-170.

WEISS H., MALUSZYNSKA J. 2001. Molecular cytogenetic analysis of polyploidyzation in the anther tapetum of diploid and autotetraploid Arabidopsis thaliana plants. Ann. Bot. 87: 729-735.

WEISS-SCHNEEWEISS H., STUESSY T.F., SILJAK-YAKOVLEV S., BAEZA C.M., PARKER J. 2003. Kariotype evolution in South American species of Hypochaeris (Asteraceae, Lactuceaea). Plant Syst Evol. 241: 171-184.

WENDEL JF. 2000. Genome evolution in polyploids. Plant Mol. Biol. 42: 225-249.

WILSON H.D. 1990. Quinua and relatives (Chenopodium sect. Chenopodium subsect. Cellulata). Econ. Bot. 44: 92-110. 